\title{
全方向移動型オドメータの開発
}

\section{Development of an Omni-Directional Odometer}

\author{
○学 青葉 祐樹 (九産大) 正 牛見 宣博（九産大） 正 鶴田 和寛（九産大） \\ Yuuki AOBA, Kyushu Sangyo University \\ Nobuhiro USHIMI, Kyushu Sangyo University, nobuhiro@ip.kyusan-u.ac.jp \\ Kazuhiro TSURUTA, Kyushu Sangyo University
}

\begin{abstract}
A lot of navigation methods for omni-directional mobile robots are proposed. In this paper, a two-wheels caster type odometer that estimates the current position and orientation of the omni-directional mobile robot is developed for the navigation. The mechanism of the developed odometer is special, and its gear train is complex. The developed odometer has a multiple rotation axis. The multiple rotation axis is composed of two shafts and bearings, and the two shafts each are possible to rotate independently. The mechanism of the multiple rotation axis transmits the different rotation of the two shafts. An estimating experiment in the current position and orientation of the omni-directional mobile robot shows the effectiveness of the developed two-wheels caster type odometer.
\end{abstract}

Key Words: Omni-directional mobile robot, Caster type odometer, Multiple Rotation Axis

\section{1.はじめに}

全方向移動ロボットにおいて特殊車輪を駆動輪に利用す る場合には，移動面との滑りが生じることや，ロボット本 体の移動中心が変化する。滑りや移動中心の変化は，駆動 輪の回転を直接エンコーダで測定し、デットレコニングに より自己位置・姿勢の推定を行う場合において問題となり， ロボットの走行制御に影響を与える $[1]$. そこで，筆者らは 駆動機構から独立した 2 輪キャス夕型オドメータを開発し,

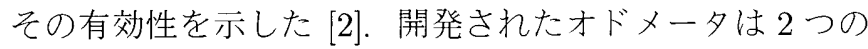
独立して回転することができる車輪と旋回軸で構成され， それぞれの回転をエンコーダに伝達し，エンコーダの值を 測定することで自己位置・姿勢の推定を可能とする。この オドメータでは左右のオドメータ車輪の異なる回転を伝達 するために，旋回軸とその旋回軸からある距離離れた回転 軸が必要となり，それら 2 軸によってオドメー夕車輪の回 転を伝達している，開発したオドメータでは，機構的に歯 車列が複雑になり, 回転を伝達する軸間距離でバックラッ シュの調整が問題となった。また。デットレコニングを行 うためには，車輪が常に移動面に接地する必要があり，路 面のうねりや段差に対応するためには，左右それぞれの才 ドメータ車輪にサスペンション機構を搭載することも開発 されたオドメータの構造上での課題として残った。

本研究では, 多重回転軸を旋回軸に使用し，全方向移動 ロボットの自己位置推定に利用可能な 2 輪キャスタ型オド メータを開発する．2つの異なる回転を多重回転軸によっ てェンコーダに伝達することで，歯車列が複雑であること による軸間距離の調整問題とサスペンション機構の構造的 な問題を回避する。開発した実機を用いて基礎実験を行い， 開発した 2 輪キャスタ型オドメータの有効性を検証する。

\section{2. 多重回転軸}

本研究で開発する 2 輪キャスタ型オドメータは，異なる $2 つ 0$ 回転を伝達する機構が必要であり，多重回転軸を利

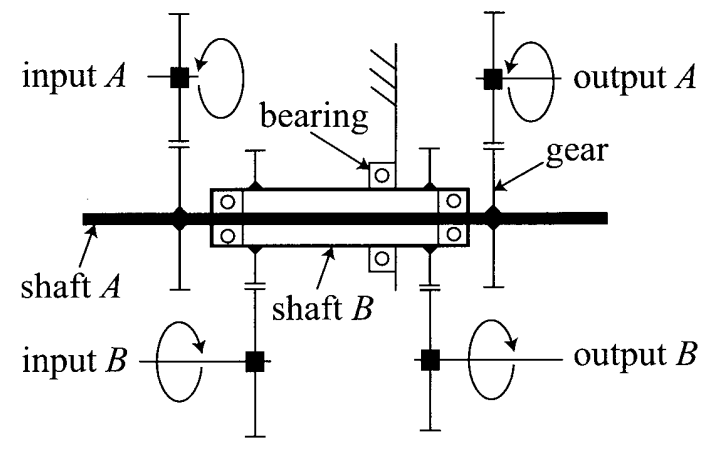

Fig.1 A multiple rotation axis with two shafts and bearings

用することで異なる回転の伝達を可能とする。

利用する多重回転軸は，図 1 のように 2 本の軸とベアリ ングによって構成される。径の異なる 2 つの軸を利用し， ベアリングを取り付けることで，それぞれの軸が独立して 回転することが可能である。例えば, 図 1 の回転入力 $A$ は，回転軸 $A$ により回転出力 $A$ を得ることができる。同 様に回転入力 $B$ は, 回転軸 $B$ により回転出力 $B$ を得るこ とができる。この機構により，2つの異なる回転を伝達す ることが可能である.

\section{2 輪キャスタ型オドメータ}

\section{$3 \cdot 1$ オドメータの原理}

2 輪キャスタ型オドメータの構成を図 2 に示す。開発す るオドメー夕は, 独立して回転する 2 つの車輪と, その回 転軸の中心からある距離を抄いて設置された旋回軸によっ

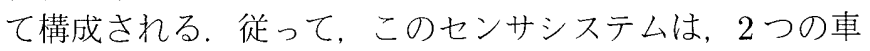
輪の回転角速度 $\omega_{R}, \omega_{L}$ と, 旋回軸での旋回角速度 $\omega_{D}$ を 独立して測定することが可能である，それらの測定結果か 


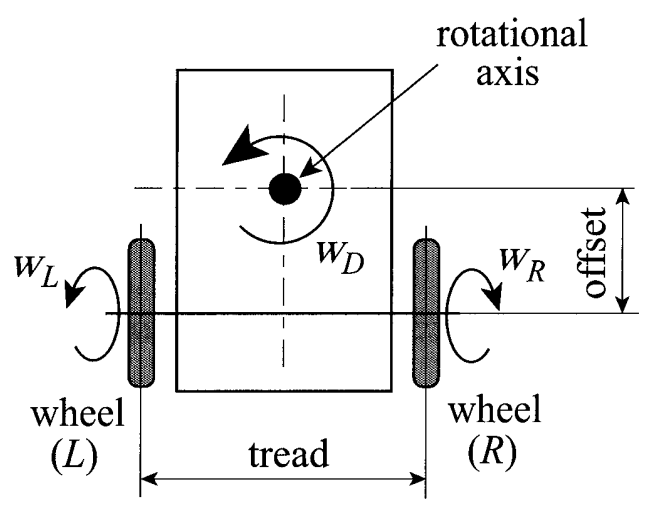

Fig.2 The odometer components

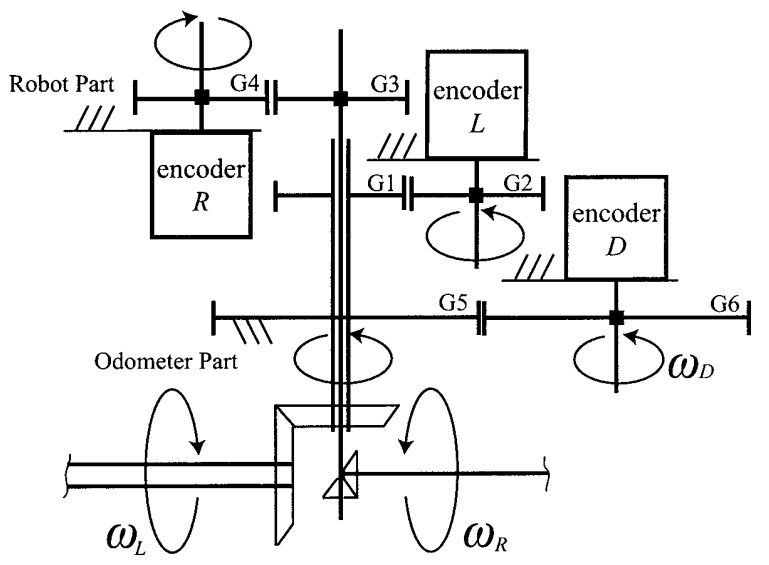

Fig.3 Gear train of the odometer

らロボットの自己位置・姿勢の推定を可能とする.

\section{2 オドメータの開発}

多重回転軸を搭載して, 2 つの車輪の回転角速度 $\omega_{R}, \omega_{L}$ と，旋回軸での旋回角速度 $\omega_{D}$ を独立してエンコーダに伝 達する。図 3 は, 平歯車とかさ歯車で構成される歯車列に よって，車輪の回転をロボット本体に搭載されたエンコー ダに伝達する機構を示す。

オドメータ車輪 $(L)$ の回転は, かさ菌車によって回転軸 を直交させ，平歯車 G2 に伝達される，さらに，平㐘車 G1 から G2 までの歯車列によって回転が伝達され，エンコー ダ $(L)$ によってオドメータ車輪 $(L)$ の回転角速度が計測 される. 同様に，オドメー夕車輪 $(R)$ の回転は，かさ歯車 によって回転軸を直交させ，平歯車 G3 に伝達される。 そ して，平歯車 G4 に回転が伝達され，エンコーダ $(R)$ に よってオドメータ車輪 $(R)$ の回転角速度が計測される．旋 回軸での回転は，オドメー夕に固定された平歯車 G5 から エンコーダ $(D)$ に取付けられた G6 に伝達され, 旋回角速 度が計測される。

開発したオドメータの外観を図 4 に示す。オドメータの 旋回部分と車輪が取り付けられた部分には，スプリングに よるサスペンション機構を搭載することで，移動面との接 地において段差やうねりに対応する。

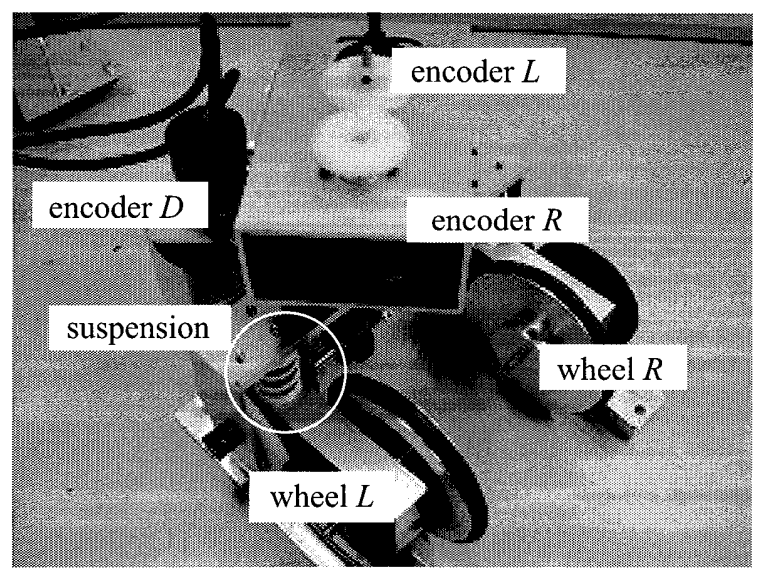

Fig.4 Photogragh of the developed odometer

\section{4. 実験}

\section{$4 \cdot 1$ 実験方法}

全方向移動ロボットを想定した 3 点支持の自由に動かす ことができるロボットフレームに，開発したオドメータを 旋回軸の中心とロボットフレームの移動中心が一致するよ うに搭載した。開発したオドメータが搭載されたロボット フレームを移動させることで，エンコーダの值を測定し， 自己位置推定実験を行った。

\section{$4 \cdot 2$ 実験結果}

開発したオドメータによって $2 つ の$ 車輪の回転角速度 $\omega_{R}, \omega_{L}$ と, 旋回軸での旋回角速度 $\omega_{D}$ を各エンコーダに 伝達できていることを確認した。この実験結果から，提案 する多重回転軸が有効に機能しているこが示された.

また，オドメータの運動学と測定結果を利用することで, 全方向移動ロボットの自己位置・姿勢を推定することが可 能である。

\section{5. おわりに}

本研究では，多重回転軸を有する 2 輪キャス夕型オド メー夕を開発した。多重回転軸を旋回軸に使用することで

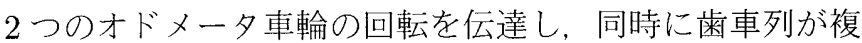
雑であることによる軸間距離のバックラッシュ調整の問題 も回避した。また，オドメータの旋回部分と車輪が取り付 けられた部分をスプリングで接続することで，左右それぞ れの車輪にサスペンション機構を搭載した。

開発したオドメータを利用した全方向移動ロボットの自 己位置・姿勢の推定に関する基礎実験を行い，旋回軸と才 ドメータ車輪の回転の測定が可能であることを検証し，全 方向移動ロボットの自己位置・姿勢の推定に有効であるこ とを示した。

\section{文 献}

[1] 和田正義，森俊二: “ホロノミック全方向移動ロボットの開発”, 日本ロボット学会誌, vol.15, no.8, pp.1139-1146 (1997).

[2] N .Usimi, M. Yamamoto, A. Mohri : "Tracking Control of Omni-Directional Vehicles Using Two Wheels Caster Type Odometer", Journal of Robotics and Mechatronics, vol.16, no.4, pp.404-410 (2004). 